\title{
The Gabay Dynasty: Plantation Jews of the Colonial Atlantic World
}

\author{
Stanley Mirvis
}

Western Sephardim of the colonial Atlantic are largely characterized as "merchants" in academic literature as well as in the popular imagination. The long distance networks of the Nação, that transcended political, linguistic, and religious borders, enabled Jewish pioneers in the Americas to exploit both clandestine and legal markets with greater facility than their non-Jewish counterparts. This New-Jewish and converso trading success, particularly in trafficking goods and slaves throughout the triangular market of Jamaica, Cuba, and Hispaniola, engendered frequent anti-Jewish hostility. Those merchants who felt threatened by Jewish trading networks in the Caribbean brought forth the frequent accusation that stateless Jews traded at the expense of agricultural settlement.

This chapter explores, through an anecdotal description of the Jamaican Gabay planting dynasty, those Jews that embraced the planter's ethos. It argues that the division between merchant and planter was not as mutually exclusive as the anti-Jewish sentiments of the early modern period would have us believe. While it is nothing new to show that Jews also planted in the Americas, this chapter provides a fuller image of Jewish plantocracy and suggests some ways a more focused view on Jewish planting may help to qualify both the historiographical representation as well as the popular imagination of colonial Atlantic Jewry.

A recent slew of popular articles about Caribbean Jews aimed at encouraging tourism, exoticizing the Jew, or enlivening the imagination with stories of Jewish swashbucklers, have reinforced an image of colonial Sephardim as an exclusively merchant community. One author characterized the Jews of Jamaica as "successful gold traders and merchants," a line that was repeated a number of times in other similar articles. ${ }^{1}$ While a statement like this is not

1 Ross Kenneth Urken, "The Forgotten Jewish Pirates of Jamaica," Smithsonianmag.com (9 July 2016). http://www.smithsonianmag.com/travel/forgotten-jewish-pirates-jamaica-18o 959252/?no-ist.

(C) STANLEY MIRVIS, 2019 | DOI:10.1163/9789004392489_024

This is an open access chapter distributed under the terms of the prevailing CC-BY-NC License at the time of publication. 
inaccurate, it completely ignores not only Jewish planters but also poor despachados, physicians, metal workers, entertainers, and fisherman.

I believe that the reluctance to mention Jewish planters in popular magazine articles is rooted in an-understandable - twenty-first-century squeamishness over the reality that Caribbean Jews owned slaves. This is likely the case for example in an outlandish piece from the Jerusalem Post online magazine, "Jewish Pirates of the Caribbean," wherein the author acknowledged Jewish planting activity but qualified that fact with the bizarre falsehood that Jews who didn't plant "were allowed only two slaves." It is possible that this hesitancy to acknowledge the full scope of Jewish slave ownership is a polemical attempt to undermine contemporary anti-Semitic libels that contend Jews were overrepresented in the slave trade or overly abusive toward their slaves. ${ }^{3}$ If that is the case then those wishing to whitewash the image of the Jewish slave owner have ironically traded in a contemporary anti-Semitic canard for an eighteenth-century one claiming that Jews traded exclusively at the expense of planting. As one member of Parliament put it in 1753: "[Jews] are not likely to become great purchasers of land, for they love their money and can employ it to much better advantage in trade." ${ }^{4}$

Academic scholarship has no less privileged the mercantile profile of the colonial Atlantic Jew. The model of the "Port Jew" in particular has come to dominate the historiographical representation of Atlantic Jewry. ${ }^{5}$ According to the "Port Jew" model, unprecedented civil liberties were granted to Jews in port cities by virtue of their value as traders. That civil liberty, coupled with a distinctively Spanish-Portuguese "alternative path to modernity," whereby Western Sephardim possessed a progressive secularism rooted in their converso past, led to the birth of Jewish modernity independent of the haskalah. Some

2 Gil Stern Zohar, "Jewish Pirates of the Caribbean," The Jerusalem Post Magazine.com (9 April 2016). http://www.jpost.com/Magazine/Jewish-pirates-of-the-Caribbean-447397. This piece was drawn from Edward Kritzler,Jewish Pirates of the Caribbean (New York: Anchor, 2008).

3 See Historical Research Department of the Nation of Islam, The Secret Relationship Between Blacks and Jews: Volume One (Chicago: Nation of Islam, 1991). For an academic rebuttal of these scurrilous claims see Eli Faber, Jews, Slaves, and the Slave Trade: Setting the Record Straight (New York: New York University Press, 1998).

4 Quoted from J.H. Hollander, "The Naturalization of the Jews in the American Colonies Under the Act of 1740," Publications of the American Jewish Historical Society (PAJHS) 5 (1897): 103$117,108$.

5 See the special issue of Jewish History "Port Jews in the Atlantic World": Jewish History 20 (2006). See also the collection of essays by David Cesarani and Gemma Romain, eds., Jews and Port Cities: 1590-1990: Commerce, Community and Cosmopolitanism (London: Vallentine Mitchell, 2006). 
scholars have already pointed to some of the potential pitfalls of this model. ${ }^{6}$ It is untrue that civil liberties were any more progressive in port cities than other places; in some cases the opposite was true. ${ }^{7}$ It is likewise a false assumption that "Port Jews" were any more "secular" than their continental counterparts. ${ }^{8}$ Finally, it has been demonstrated that Atlantic "Port Jews" did in fact have a rich and consistent engagement with the European Enlightenment throughout the eighteenth century. 9

In this chapter I hope to further problematize the model of the "Port Jew" by emphasizing the experience of "Plantation Jews" who were both dependent on yet independent of their port-city brethren. ${ }^{10} \mathrm{I}$ hope to point to some ways in which "Plantation Jews" experienced their own trajectory toward modernity by exploring their transition from agricultural investment to direct plantation ownership through the lives of the Jamaican planter dynasty, the Gabays.

Salamão Gabay was born a New Christian in Portugal who embraced his ancestral Judaism in Amsterdam. ${ }^{11}$ By the 1640 s he had joined the Dutch "New Jewish"

6 See C.S. Monaco, "Port Jews or a People of the Diaspora? A Critique of the Port Jew Concept," Jewish Social Studies 15, no. 2 (2009): 137-66.

7 See Stanley Mirvis, "Between Assembly and Crown: The Debate Over Jewish Taxation in Jamaica (1692-1740)" Journal of Early American History 6 (2016): 196-219.

8 See for instance Yosef Kaplan, From Christianity to Judaism: The Story of Isaac Orobio de Castro (Oxford: Littman Library of Jewish Civilization, 2004) who argues that the converso university experience did not necessarily produce skepticism or secularism. For an important analysis of the meaning of secularization in the Jewish eighteenth century see Shmuel Feiner, The Origins of Jewish Secularization in Eighteenth-Century Europe (Philadelphia: University of Pennsylvania Press, 2011).

9 See in this volume, Sina Rauschenbach, "Patriots at the Periphery: David Nassy, the French Revolution, and the Emancipation of the Dutch Jews." Jacob Rader Marcus, ed., Historical Essay on the Colony of Surinam, 1788 (Cincinnati: American Jewish Archives, 1974). See also Stanley Mirvis, "Joshua Hezekiah Decordova and a Rabbinic Counter-Enlightenment from Colonial Jamaica," in Reappraisals and New Studies of the Modern Jewish Experience: Essays in Honor of Robert M. Seltzer (Leiden: Brill, 2015), 104-22. David B. Ruderman, Jewish Enlightenment in an English Key: Anglo-Jewry's Construction of Modern Jewish Thought (Princeton, NJ: Princeton University Press, 2012).

10 The term "Plantation Jew" was introduced by Dale Rosengarten, "Port Jews and Plantation Jews, Carolina-Caribbean Connections," in The Jews in the Caribbean, ed. Jane S. Gerber (Oxford: The Littman Library of Jewish Civilization, 2014), 289-307.

11 Egon and Frieda Wolff, Dicionário Biográfico:Judaizantes e Judeus no Brasil, 1500-1808 (Rio de Janeiro: Instituto Histórico e Geográfico Brasileiro, 1986), 82-83. 
settlement of Pernambuco where he trafficked in foodstuffs and slaves. An active participant in the Portuguese Jewish community of Recife, he was among the signatories to the communal regulations of Zur Israel along with at least three of his male relatives. ${ }^{12}$ After the Portuguese conquest of Pernambuco, and subsequent expulsion of the Jews in 1654, Salamão appears to have returned to Amsterdam from where he later sailed on to Jamaica. In Jamaica he laid the foundation for one of the island's most resilient and long lasting Jewish planting dynasties. As with so many other Jewish refugees from Brazil, such as the famous Martinique sugar mogul Benjamin Dacosta D'Andrade, Salamão translated his commercial involvement in Brazilian planting into actual Caribbean plantation ownership. ${ }^{13}$

While the Jews of Recife, by-and-large, played only a supportive role in Brazilian sugar planting through the acquisition and resale of slaves and capital investment, New Christians had been intimately involved in planting since the sixteenth century. Portuguese conversos poured into Brazil during the late sixteenth and seventeenth centuries. Conversos and conversas, mostly women, convicted of Judaizing by the Portuguese Inquisitions made up more than half of those punitively exiled to Brazil. ${ }^{14}$ Some early New Christian arrivals to Brazil belonged to families who already possessed sugar-planting expertise acquired on the Portuguese possession of Madeira off the west coast of Africa. ${ }^{15}$ While they were not the dominant force behind Brazil's sugar boom, converso "senhores de engenho" were among the leading pioneers of Bahian sugar production.

Far across the "Ocean Sea," seemingly hidden from the surveillance of the Lisbon Inquisition, Brazilian sugar plantations provided a fecund space for the continuity of crypto-Jewish practices. Some engenhos may have even provided spaces for the semi-public practice of crypto-Judaism. ${ }^{16}$

12 Arnold Wiznitzer, The Records of the Earliest Jewish Community in the New World (New York: American Jewish Historical Society, 1954), 51.

13 On Benjamin Dacosta d'Andrade see Isaac S. Emmanuel, Precious Stones of the Jews of Curaçao: Curaçaon Jewry 1656-1957 (New York: Bloch, 1957), 200-1. For examples of other Brazilian exiles who invested in Caribbean plantations see Stanley Mirvis, "The Alvares Family Patriarchs and the Place of Pre-1692 Port Royal in the Western Sephardic Diaspora," The American Jewish Archives Journal 67, no. 2 (2015): 1-46.

14 Geraldo Pieroni, "Outcasts from the Kingdom: The Inquisition and the Banishment of New Christians to Brazil," in The Jews and the Expansion of Europe to the West, 1450 to 180o, ed. Paolo Bernardini and Norman Fiering (New York: Berghahn Books, 2001), 242-51, 245.

15 Ernst Pijning, "New Christians as Sugar Cultivators and Traders in the Portuguese Atlantic, 1450-180o" in Jews and the Expansion of Europe to the West, 485-500, 487.

16 Stuart B. Schwartz, Sugar Plantations in the Formation of Brazilian Society: Bahia, 1500-1835 (Cambridge: Cambridge University Press, 2004), 266. 
As in the rest of the Atlantic World, the wealth generated from sugar production in the Portuguese Atlantic did not necessarily result in an improvement of social status. For New Christians it was easier to transcend one's economic status than one's stained blood. While they had acquired wealth, they remained stigmatized by their Jewish ancestry and excluded from full participation in civil society.

In 1629, the States-General in Holland declared that in the West Indian Company (WIC) possession of Pernambuco, "The liberty of Spaniards, Portuguese and natives, whether they be Roman Catholics or Jews will be respected."17 Unlike in northwestern Europe where the rejudaized fled to "terras de libertad," in Brazil, the "terras de libertad" came to them. The Dutch occupation of Pernambuco dramatically accelerated contact between these two strands of the Nação — crypto-Jews and New Jews—giving rise to an unprecedentedly rapid rejudaization movement. ${ }^{18}$

The Dutch governor of Pernambuco Johan Maurits redistributed abandoned sugar mills in an effort to encourage Catholic sugar planters to relocate to Dutch territory. ${ }^{19}$ Despite the absence of economic or social barriers, the Jews of Dutch Brazil did not immediately gravitate toward direct plantation ownership. It is estimated that Jews owned only about six percent of the Dutch Brazilian engenhos. ${ }^{20}$ The historian Arnold Wiznitzer wrote: "It cannot be said that Jews played a dominant role in Dutch Brazil as senhores de engenho. Unquestionably, they played a more important part as financiers of the sugar industry, as brokers and exporters of sugar, as suppliers of Negro slaves on credit, accepting payment of capital and interest in sugar." ${ }^{21}$

Unlike their New Christian counterparts, newly arrived Jews in Dutch Pernambuco, such as Salamão Gabay, were indeed traders and investors rather than growers of sugar. ${ }^{22}$ Their extensive involvement in the sugar trade echoed in the communal minutes of the colony where the Mahamad, set the impos$t a$ for sugar exports at eight soldos per unit for refined sugar and six soldos per unit for muscovado. The same rates applied for the sale of imported sugar.

\footnotetext{
17 Wiznitzer, The Records of the Earliest Jewish Community, 1.

18 Bruno Feitler, "Jews and New Christians in Dutch Brazil, 1630-1654," in Atlantic Diasporas: Jews, Conversos, and Crypto-Jews in the Age of Mercantilism, ed. Richard L. Kagan and Philip D. Morgan (Baltimore: The Johns Hopkins University Press, 2009), 123-51.

19 Arnold Wiznitzer, Jews in Colonial Brazil (New York: Columbia University Press, 1960), $67-68$.

20 Wiznitzer, Jews in Colonial Brazil, 69 .

21 Ibid., 70.

22 Pijning, "New Christians as Sugar Cultivators," 491.
} 
Retailers of sugar produced and consumed locally were required to pay only half the imposta. ${ }^{23}$

The Recife Mahamad similarly regulated the ownership of African slaves. Taking liberties with rabbinic tradition, they required in 1649 that a slave be manumitted before being subject to circumcision and, seemingly, only if he chose circumcision. ${ }^{24} \mathrm{~A}$ nearly identical ordinance passed in Amsterdam a year later. The reality of Jewish slave ownership in the colonial Americas made it unfeasible to follow the biblical standard of circumcising slaves upon purchase [Genesis 17:12]. Jewish traders of Recife purchased large numbers of slaves from the WIC for resale to the engenhos.

The Jews of Recife like Salamão Gabay clearly possessed a mercantile ethos, even if it was one deeply engrained in the plantation culture of Brazil. The WIC, however, while pragmatically encouraging Jewish trading activity, also hoped that Jews would participate more fully in agriculture. The Dutch had taken possession of Spanish Curaçao in 1634 . By the 1650 s, rising hostilities between the Dutch and the Portuguese in Brazil prompted Jewish leaders in Amsterdam to seek permission from the WIC to establish new Jewish settlements there. ${ }^{25}$ The WIC granted permission to various Jewish settlement schemes such as that of the Sabbatean mystic João de Ilan, because he intended to "bring a considerable number of people there to settle and cultivate [...] the land."26 The directors of the WIC suspected, however, that his true intentions were to trade. They wrote in the same letter to Governor Peter Stuyvesant: "we begin to suspect, that he and his associates have quite another object in view, namely, to trade from there to the West Indies and the [Spanish] Main." Already in the earliest years of Jewish settlement in the Americas the tension between trader and planter generated an anti-Semitic image of the Jew as merchant at the exclusion of planter.

\section{Salamão Gabay and the Port Royal Merchant-Planters}

Upon the Portuguese expulsion of Jews from Pernambuco, Salamão Gabay seems to have returned to Amsterdam. From there he sailed back to the

\footnotetext{
23 Wiznitzer, The Records of the Earliest Jewish Community, 74.

24 Jonathan Schorsch, Jews and Blacks in the Early Modern World (Cambridge: Cambridge University Press, 2004), 74-79, 219-226. Wiznitzer, The Records of the Earliest Community, 69.

25 See Isaac S. Emmanuel and Suzanne A. Emmanuel, History of the Jews of the Netherlands Antilles, 2 vols. (Cincinnati: American Jewish Archives, 1970), 1: 37-50.

26 Hebert Cone, "The Jews in Curaçao: According to Documents from the Archives of the State of New York," PAJHS 10 (1902): 141-57, here 147.
} 
western side of the Atlantic to settle on the English island of Jamaica where he became a free denizen in $1672 .{ }^{27}$ His denization entitled him to purchase land, arbitrate disputes in court, and trade freely (within the confines of the law) although he was excluded from civil service and participation in the colony's governance. Salamão's settlement in Jamaica appears to have been a family venture. Possibly the oldest known Jewish tombstone at Hunt's Bay Cemetery, across the bay from Port Royal on the western outskirts of modern-day Kingston, belonged to one Abraham Gabay who died in the spring of $1672 .{ }^{28}$

Salamão and his kinsmen joined the founders of the Jewish community of Port Royal, many of whom had likewise been members of the Recife community. He, along with his relative, Abraham de David Gabay, and Moses Yeshurun Cardoso "acting [on behalf of] the rest of the Jews [...] residing in Port Royal" signed a deed in January of 1677 to purchase Jewish communal land, possibly intended for the erection of a synagogue. ${ }^{29}$ Port Royal provided a welcome environment for Portuguese Jews. At the behest of the colonial authorities in London, the Governor of Jamaica Thomas Lynch declared religious liberty to Jews and Protestant dissenters in 1670 with the pragmatic intention of profiting from their extensive channels of trade. ${ }^{30}$ Jews integrated well into Port Royal's renowned ethnic and religious diversity typical of port cities of the period. ${ }^{31}$

The Jewish settlers in Port Royal quickly capitalized on their transAtlantic networks flouting the English restrictions on trade with the Castilian Americas - empowered by the implementation of the Asiento in 1713 - as well as to Dutch territories. Stiff competition over trade in Port Royal prompted the non-Jewish merchants to initiate a vigorous campaign against Jewish trading efforts sending at least two petitions up the chain of colonial command between 1671 and $1684 .{ }^{32}$

27 Wolff and Wolff, Dicionário Biográfico, 82-83.

28 Richard D. Barnett and Philip Wright, The Jews of Jamaica: Tombstone Inscriptions, $1663^{-}$ 1880 (Jerusalem: Ben Zvi Institute, 1997), 5, no. 12. This is the oldest known Jewish tombstone according to Rachel Frankel and her Caribbean Volunteer Expedition of 2008, see Rachel Frankel, "Testimonial Terrain: The Cemeteries of New World Sephardim" in The Jews of the Caribbean, 131-42, 133 n. 5 .

29 Jacob Andrade, A Record of the Jews in Jamaica from the English Conquest to the Present Times (Kingston: Jamaica Times, 1941), 40. See also Michael Pawson and David Buisseret, Port Royal, Jamaica (Kingston: University of the West Indies Press, 2000), 129.

J.W. Fortescue, ed., Calendar of State Papers, Colonial America and the West Indies (London: Her Majesty's Stationary Office, 1898), 8: 145-47.

31 David Buisseret, ed., Jamaica in 1687: The Taylor Manuscript at the National Library of Jamaica (Kingston: University of West Indies Press, 2010), 238.

Mirvis, "The Alvares Family Patriarchs," 8. 
These petitions were written with anti-Jewish language echoing earlier anti-Jewish petitions from Barbados. Barbadian merchants submitted no fewer than four anti-Jewish trading petitions, employing archetypal antiJewish stereotypes, between 1661 and $1680 .{ }^{33}$ Though Barbadian Jews attempted to defend themselves, their defense was not necessary, as the Board of Trade in London remained committed to encouraging Jewish trading activity. But, local assemblies responded to these petitions by imposing a collective Jewish tax in both Jamaica and Barbados. In Jamaica, where the tax would persist on an annual basis until 1740, proponents often justified it on the grounds that Jews refrained from planting. When the Jamaican governor William Beeston - a man with a track record of anti-Jewish positions-instituted the Jewish tax in Jamaica, he justified it by saying that the Jews' "first introduction into this Island was upon condition that they should settle and plant, which they do not." ${ }^{34}$

These petitions in the English Caribbean have helped shape an image of Jews in the colonial Americas as single-minded traders to this day. It is easy to reach the same conclusion through the available notarial and cemetery records where Jews are almost always referred to as "merchant." However, the term merchant is misleading since "merchants" and "planters" are not mutually exclusive categories. Sugar planting in particular required extensive capital investment for which Jamaican planters relied heavily on Kingston traders. ${ }^{35}$ Jamaica's earliest Jews, recapitulating their Brazilian profile, actively invested their earnings in plantations. From there it was a small step toward actual plantation ownership. Port Royal Jews defended themselves against mercantile hostilities by touting their plantation ownership.

In August of 1692, nearly three months after the devastation of Port Royal by an earthquake and tidal wave, the Jewish survivors-along with their Barbadian counterparts-petitioned the Queen directly asking for denization because they had become destitute by the calamity. ${ }^{36}$ To prove their value to the colony they emphasized their planting activity. The petition was sent by the twenty-one heads of the "Jews' plantations and houses in Jamaica and

33 Stephen A. Fortune, Merchants and Jews: The Struggle for British West Indian Commerce, 1650-1750 (Gainesville: University of Florida Press, 1984), 45-46.

34 See Mirvis, "Between Assembly and Crown," 208.

35 Nuala Zahedieh, "Trade, Plunder, and Economic Developments in Early English Jamaica, 1655-1689," The Economic History Review 39, no. 2 (1986): 205-22.

36 "Memorandum of the Jews of Jamaica (August, 1692)," The National Archives Kew, England (TNA) CO 137/2, 112. See a reproduction in Frank Cundall, N. Darnell Davis, and Albert M. Friedenberg, "Documents Relating to the History of the Jews in Jamaica and Barbados in the Time of William III," PAJHS 23 (1915): 25-29, 27-29. 
Barbados." Solomon [Salamão] Gabay was among the twelve planters representing Jamaica. The petition described him as having operated a "plantation for many years in Magitt Savana." His kinsman Abraham Gabay owned a plantation in "White Hood." Sarah Gabay was the only woman planter on the list. Clearly, already by 1692, the Gabays had translated their expertise financing plantations into actual plantation ownership.

This petition came at a critical time of transition in Jamaica. Even before the earthquake, Jamaica had begun a metamorphosis into a sugar-based economy. By 1680 , colonial authorities increasingly pursued policies intended to marginalize privateering with the goal of developing the agricultural promise of Jamaica's interior. ${ }^{37}$ The sheer scale of available planting land that far outstripped Barbados, presented the possibility of challenging France's Caribbean sugar hegemony. The 1692 earthquake and resultant destruction of England's most profitable Caribbean trading hub provided a further impetus to turn the attention of the island's inhabitants toward sugar planting. This is precisely what the twelve Jamaican planter families were responding to when they petitioned the crown in 1692. In doing so they made the case not only for their willingness to transcend the stereotypically Jewish attachment to trade, but, to make the case clear to the Crown that they had already been planting in Jamaica.

The Gabay dynasty of Jamaica founded by the Brazilian expellee Salamão remained at the cutting edge of Jamaica's transformation into a monoculture sugar colony. Three generations of Gabays lived and planted in Jamaica between 1680 and 1740 . David Gabay (the elder) resided in the small hamletcum political capital—St. Jago de la Vega (Spanish Town), a place notable for its planter residents, and composed a will in 1720 where he bequeathed his plantation in the parish of St. Thomas in the Vale to his son Isaac. ${ }^{38}$ Isaac Gabay, who also lived in St. Jago de la Vega, continued to operate his father's plantation and made more extensive mention of enslaved property in his will of June $1730 .{ }^{39} \mathrm{He}$ supported both his daughter and his unborn child with slaves, while he bequeathed the family plantation to his son David (the younger). Isaac further requested that two slaves be purchased for his daughter, Rebecca, from the first "negro ship that arrives after my decease." David (the younger) had still

37 Richard S. Dunn, Sugar and Slaves: The Rise of the Planter Class in the English West Indies, 1624-1713 (Chapel Hill, NC: The University of North Carolina Press, 1972, repr. 2000), $154-65$.

38 "Will of David Gabay, 1720," Island Records Office, Twickenham, Jamaica (hereafter I Ro) lib. 15 fol. 267 .

39 "Will of Isaac Gabay, 1732," IRo lib. 18 fol. 165; American Jewish Archives, Cincinnati, Ohio (AJA) SC-3836. 
been operating the profitable family sugar plantation in St. Thomas in the Vale at the time he drafted his will in July of $1738 .{ }^{40}$

\section{The Gabays of Plantation Jamaica}

The shift toward monoculture sugar production in Jamaica was a slow one fraught with fits and starts. Historians of the British West Indies see the period between 1680 and 1740 as one of transition..$^{41}$ While the political will from both the colonial authorities in London and the Assembly was there as early as 1680, a number of factors delayed Jamaica's transition from privateering port to sugar factory. Political policy promoting plantations remained inchoate. Planters lacked sufficient capital. Still dependent on white indentured labor, the colony lacked sufficient numbers of African slaves to pursue the labor-intensive sugar production on the scale of Saint-Domingue or Portuguese Brazil. Conflict with Maroon communities, particularly in the northeastern reaches of the island, prevented settlers from cultivating much of the available plantation land.

By 1740 the situation had changed. The abolition of the Asiento and the humiliation of the Spanish during the War of Jenkins' Ear (1739-1742) brought slaves into the island at a higher rate. Legislation from the metropole such as the Molasses Act (1733) enabled the large-scale production of muscovado and eliminated competition in the sugar trade from other English American colonies. The peace treaty with the Maroons (1740) made it possible for Jamaican planters to expand into uncultivated northeastern territories of the island.

One of the metropole policies leading to the dominance of sugar affected the Jews directly. The so-called "Plantation Act" of 1740 encouraged foreigners to settle in English colonies by offering naturalization to anyone with uninterrupted residence in an American colony for a period of seven years. The Act targeted Jews explicitly by removing a Christian oath and passed nearly uncontested in Parliament (unlike its English counterpart in 1753). Around 150 Jews in Jamaica were naturalized as a direct result of the Plantation Act. ${ }^{42}$ Though not stated explicitly, the spirit of the Act was that Jews would be encouraged to participate more fully in the push toward planting thereby forsaking their perceived insistence on trade.

\footnotetext{
$40 \quad$ "Will of David Gabay (the younger), 1762," I Ro lib. 34 fol. 9; AJA, SC-3835.

41 See Verene Shepherd, Livestock, Sugar and Slavery: Contested Terrain in Colonial Jamaica (Kingston: Ian Randle Publishers, 2009), 14-23.

42 Hollander, "The Naturalization of the Jews," 110.
} 
Furthermore, this Act came at a time when opportunities for Jews had been rapidly diminishing in other parts of the sugar-producing Caribbean region. While some Jews managed to remain in Saint-Domingue after the expulsion from the French Caribbean in 1685 and even participate to a limited extent in the sugar monoculture of that island-usually as converts-it was moreor-less closed off to Jewish participation. ${ }^{43}$ The scale of sugar production in Jamaica far outstripped that of Barbados by the second decade of the eighteenth century. Curaçao's arid climate and frequent drought made it untenable as a plantation society. Suriname was the only possible rival in the Dutch sphere of influence where Portuguese Jews had a long tradition of planting and slave ownership in their village of Jodensavanne. However, tensions with local Maroon communities, the remoteness of the plantations, along with the bursting of an investment bubble in Amsterdam, all conspired against Surinamese planters. ${ }^{44}$ Suriname was simply uncompetitive compared to English Jamaica or French Saint-Domingue. By the 1770s, Jews had largely abandoned their Surinamese plantations.

Having built a strong foundation since the time of the earliest settlement, the Gabays expanded their efforts during the period referred to as "Plantation Jamaica"45_a period characterized by monoculture sugar production along with its increasing reliance on "industrialized" and ever more brutal forms of slavery. During the $1750 \mathrm{os}$ and 6os, small Gabay-owned plantations dotted the Jamaican landscape. In 1750, Samuel, Isaac, and Solomon Gabay owned and operated between them nearly 1,400 acres of land throughout the island including in St. Catherine, St. Elizabeth, St. John, and St. Thomas in the Vale, where Isaac and Solomon Gabay together possessed around one thousand acres known as "Magotty Sugar Works." 46 Gabay-owned plantation property was so widely dispersed throughout the island during this period that other testators bequeathed land in their wills previously owned by Gabays. Daniel Rodrigues Nunes from Vere Parish, for instance, composed a will in December of 1773 where in addition to his beachfront house near Carlisle Bay on the

43 See John D. Garrigus, "New Christians/'New Whites' Sephardic Jews, Free People of Color, and Citizenship in French Saint-Domingue, 1760-1789," in The Jews and the Expansion of Europe to the West, $315-32$.

44 See Robert Cohen, Jews in another Environment: Surinam in the Second Half of the Eighteenth Century (Leiden: Brill, 1991), 71-72. Wieke Vink, Creole Jews: Negotiating Community in Colonial Suriname (Leiden: KITLV Press, 2010), 47-48.

45 See B.W. Higman, Plantation Jamaica, 1750-1850: Capital and Control in a Colonial Economy (Kingston: University of West Indies Press, 2008).

46 "Jamaican Land Owners (1750)," The British Library, London England, BA Add MS. 12436. "Will of Solomon Gabay, 1743," I Ro lib. 23 fol. 193. 
southern coast of the island, he divided among his beneficiaries a modest 104acre plantation where he dwelled in Vere "commonly called Gabay's." 4

The St. Catherine planter Samuel Gabay died in his early sixties after drafting a will in August of $1747 .{ }^{48}$ Samuel was decidedly more connected to the Jewish community than his other planter kin. In his will he made charitable contributions to poor Jews, supported three synagogues on the island, and also requested that his executors purchase a tombstone to mark his grave. That tombstone contained only Portuguese, at the exclusion of either English or Hebrew. ${ }^{49}$ Samuel appears to be the first Gabay planter to manumit slaves in his will: three older women..$^{50}$ At the same time as these manumissions, he also bequeathed to his (seemingly second) wife and their infant son, two female and two male household slaves along with her choice of one of three houses in St. Jago de la Vega.

The St. Catherine planter David Gabay composed a will in September of 1760 where he made a donation to Neve Shalom in St. Jago de la Vega in return for an escava (hashkhava) to be recited on the night of Yom Kippur. ${ }^{51}$ While he supported his pregnant wife Rachel, née Ydana, and three children with slaves and monetary assets, he gave his land referred to as "Salt Ponds" in St. Catherine to his married sister Rebecca Dias Arias along with four individual slaves. Among the twenty slaves mentioned in his will, he manumitted a single woman named Mary and provided her with a one-time token sum of five Jamaican pounds.

Samuel and David Gabay's wills are highly symbolic of Jamaica's shift toward "industrialized" slavery and sugar production. They both lived among the Island's plantocracy in St. Jago de la Vega and seemed to have no discernable interest in Kingston commerce. The prominent place of the enslaved in their wills, especially in comparison to the Gabay planters of the 1720s-30s, is representative of Jamaica's transition into a slave society.

\section{Conclusion}

Following their exile from Brazil, the Gabay family translated their capital investment and trade in sugar into actual plantation ownership. In Jamaica, their

\footnotetext{
47 "Will of Daniel Rodrigues Nunes, 1774," I Ro lib. 42 fol. 27.

48 "Will of Samuel Gabay, 1751," IRo lib. 28 fol. 86.

49 Barnett and Wright, The Jews of Jamaica, 91, no. 1046.

5o On Manumission see Rosemary Brana-Shute and Randy J. Sparks, eds. Paths to Freedom: Manumission in the Atlantic World (Columbia, SC: University of South Carolina Press, 2009).

$5^{1} \quad$ "Will of David Gabay, 176o," IRo lib. 32 fol. 186.
} 
plantation ownership mirrored the various phases of transition from merchant colony to sugar factory. Like other Port Royal Jews, they were merchantplanters. During the period of transition from 1680 to 1740 the descendants of Salamão Gabay operated small plantations with modest enslaved African workforces peppered throughout the island. By the 1750s, they had emerged as St. Catherine plantocracy with large sugar works utilizing the labor of large enslaved workforces. Despite the wealth generated from planting, Jamaican Jews, like the New-Christians of Brazil, could never hope to transcend their social status as foreigners and fit uncomfortably within Jamaica's racial hierarchy. ${ }^{52}$

It is already well established that Jews were planters in the Caribbean region. This anecdotal chapter is meant to promote future research that will explore more fully the impact of plantation life on "Plantation Jews." Even though they did not stand completely apart from the port-city merchants of the Atlantic and often were one and the same, they still defy characterization as exclusively "merchants" in the "Port-Jew" model. While some Jamaican Jewish planters maintained residence in port cities such as Kingston, the Gabays found their fortunes in the planter and political capital of St. Jago de la Vega. Already by the 1720 s they had become a Spanish-Town dynasty no doubt embracing the political interests and social life of that planter's hamlet. ${ }^{53}$ The planter Jews of Suriname, particularly in the jungle town of Jodensavanne, likewise cannot be described as "Port Jews." Deepening our understanding of Jewish plantation ownership will enable us to shift the focus on Atlantic Jewry away from port cities and trading activity.

More importantly is the potential to understand the path toward modernity of "Plantation Jews" in terms of creolization rather than secularization. As with the Gabays, plantation ownership brought Jews into close contact with the enslaved. While these contacts were violent and exploitive, they were just as much transformative. Jewish planters frequently raped or "sexploited" their female plantation and household slaves. ${ }^{54}$ These abusive relationships transformed the complexion of the "Plantation Jew" and also expanded Spanish-Portuguese notions of familial belonging and blood purity, further distancing themselves from their more endogamous port-Jewish brethren. Many of Jamaica's planter Jews lived in non-legally recognized Creole families of color. Contact with the enslaved also brought about

$5^{2}$ On the inability to transcend racialized categories in Jamaica see Shepherd, Livestock, Sugar and Slavery, 112.

53 James Robertson, Gone is the Ancient Glory: Spanish Town, Jamaica, 1534-200o (Kingston: Ian Randle Publishers, 2005).

54 See Stanley Mirvis, "Sephardic Family Life in the Eighteenth-Century British West Indies," PhD diss., The Graduate Center of the City University of New York, 2013, 84-110. 
cultural changes. Increasingly, by the late eighteenth century, Europeans perceived Creole planters as completely alien to European cultural values and characteristics. ${ }^{55}$ Further research must be devoted to understanding exactly how those Creole characteristics defined "Plantation Jews" such as the Gabays.

While this chapter offers only a preliminary and anecdotal discussion of the "Plantation Jew," I hope it will encourage future researchers-both academic and popular-to decentralize the concept of the heavily mercantile "Port Jew" from the story of colonial Atlantic Jewry. The term merchant must be expanded to include plantation ownership in consideration of the possibility that our over characterization of colonial Atlantic Jews as "merchants" is not a reflection of reality but rather informed by anti-Semitic libels of the eighteenth century. Likewise, we must consider the possibility that our over reliance on the term "merchant" is an attempt to sidestep the uncomfortable truth of Jewish slave ownership in the colonial Atlantic.

\section{Bibliography}

The American Jewish Archives, Cincinnati, Ohio.

Andrade, Jacob. A Record of the Jews in Jamaica from the English Conquest to the Present Times. Kingston: Jamaica Times, 1941.

Barnett, Richard D., and Philip Wright. The Jews of Jamaica: Tombstone Inscriptions, 1663-1880. Jerusalem: Ben Zvi Institute, 1997.

Bernardini, Paolo, and Norman Fiering, eds. The Jews and the Expansion of Europe to the West, 145 o to 180o. New York: Berghahn Books, 2001.

Brana-Shute, Rosemary, and Randy J. Sparks, eds. Paths to Freedom: Manumission in the Atlantic World. Columbia, SC: University of South Carolina Press, 2009.

Buisseret, David, ed. Jamaica in 1687: The Taylor Manuscript at the National Library of Jamaica. Kingston: University of West Indies Press, 2010.

Burnard, Trevor, and John Garrigus. The Plantation Machine: Atlantic Capitalism in French Saint-Domingue and British Jamaica. Philadelphia: University of Pennsylvania Press, 2016.

Cesarani, David, and Gemma Romain, eds. Jews and Port Cities: 1590-1990: Commerce, Community and Cosmopolitanism. London: Vallentine Mitchell, 2006.

55 Trevor Burnard and John Garrigus, The Plantation Machine: Atlantic Capitalism in French Saint-Domingue and British Jamaica (Philadelphia: University of Pennsylvania Press, 2016), 264. 
Cohen, Robert. Jews in another Environment: Surinam in the Second Half of the Eighteenth Century. Leiden: Brill, 1991.

Cone, Herbert. "The Jews in Curaçao: According to Documents from the Archives of the State of New York," Publications of the American Jewish Historical Society 10 (1902): 141-157.

Cundall, Frank., N. Darnell Davis, and Albert M. Friedenberg, "Documents Relating to the History of the Jews in Jamaica and Barbados in the Time of William III," Publications of the American Jewish Historical Society 23 (1915): 25-29.

Emmanuel, Isaac S. Precious Stones of the Jews of Curaçao: Curaçaon Jewry 1656-1957. New York: Bloch, 1957.

Emmanuel, Isaac S., and Suzanne A. Emmanuel. History of the Jews of the Netherlands Antilles. Vol. 1. Cincinnati: American Jewish Archives, 1970.

Faber, Eli. Jews, Slaves, and the Slave Trade: Setting the Record Straight. New York: New York University Press, 1998.

Feiner, Shmuel. The Origins of Jewish Secularization in Eighteenth-Century Europe. Translated by Chaya Naor. Philadelphia: University of Pennsylvania Press, 2011.

Fortescue, J.W. ed. Calendar of State Papers, Colonial America and the West Indies. Vol. 8. London: Her Majesty's Stationary Office, 1898.

Fortune, Stephen A. Merchants and Jews: The Struggle for British West Indian Commerce, 1650-1750. Gainesville: University of Florida Press, 1984.

Gerber, Jane, ed. The Jews in the Caribbean. Oxford: The Littman Library of Jewish Civilization, 2014.

Higman, B.W. Plantation Jamaica, 1750-1850: Capital and Control in a Colonial Economy. Kingston: University of West Indies Press, 2008.

Hollander, J.H. "The Naturalization of the Jews in the American Colonies Under the Act of 1740." The Publications of the American Jewish Historical Society 5 (1897): 103-17.

The Island Records Office, Twickenham, Jamaica.

Kagan, Richard L. and Philip D. Morgan, eds. Atlantic Diasporas: Jews, Conversos, and Crypto-Jews in the Age of Mercantilism Baltimore: The Johns Hopkins University Press, 2009.

Kaplan, Yosef. From Christianity to Judaism: The Story of Isaac Orobio de Castro. Oxford: Littman Library of Jewish Civilization, 1989.

Marcus, Jacob R., ed. Historical Essay on the Colony of Surinam, 1788. Cincinnati: American Jewish Archives, 1974.

Mirvis, Stanley. "Sephardic Family Life in the Eighteenth-Century British West Indies." PhD diss., The Graduate Center of the City University of New York, 2013.

Mirvis, Stanley. "The Alvares Family Patriarchs and the Place of Pre-1692 Port Royal in the Western Sephardi Diaspora." The American Jewish Archives Journal 67, no. 2 (2015): $1-46$. 
Mirvis, Stanley. "Between Assembly and Crown: The Debate Over Jewish Taxation in Jamaica (1692-1740).” Journal of Early American History 6 (2016): 196-219.

Monaco, C.S. "Port Jews or a People of the Diaspora? A Critique of the Port Jew Concept." Jewish Social Studies 15, no. 2 (2009): 137-66.

The National Archives, Kew, England.

Pawson, Michael, and David Buisseret. Port Royal, Jamaica. Kingston: University of the West Indies Press, 2000.

Robertson, James. Gone is the Ancient Glory: Spanish Town, Jamaica, 1534-2000. Kingston: Ian Randle Publishers, 2005.

Ruderman, David B. Jewish Enlightenment in an English Key: Anglo-Jewry's Construction of Modern Jewish Thought. Princeton, NJ: Princeton University Press, 2012.

Schorsch, Jonathan. Jews and Blacks in the Early Modern World. Cambridge: Cambridge University Press, 2004.

Schwartz, Stuart B. Sugar Plantations in the Formation of Brazilian Society: Bahia, 15001835. Cambridge: Cambridge University Press, 2004.

Shepherd, Verene. Livestock, Sugar and Slavery: Contested Terrain in Colonial Jamaica. Kingston: Ian Randle Publishers, 2009.

Smollett, Brian, and Christian Wiese. Reappraisals and New Studies of the Modern Jewish Experience: Essays in Honor of Robert M. Seltzer. Leiden: Brill, 2015.

Urken, Ross Kenneth. "The Forgotten Jewish Pirates of Jamaica," Smithsonianmag .com, July 7, 2016, https://www.smithsonianmag.com/travel/forgotten-jewishpirates-jamaica-180959252/.

Vink, Wieke. Creole Jews: Negotiating Community in Colonial Suriname. Leiden: KITLV Press, 2010.

Wiznitzer, Arnold. Jews in Colonial Brazil. New York: Columbia University Press, 1960.

Wiznitzer, Arnold. The Records of the Earliest Jewish Community in the New World. New York: American Jewish Historical Society, 1954.

Wolff, Egon, and Frieda Wolff. Dicionário Biográfico: Judaizantes e Judeus no Brasil, 1500-1808. Rio de Janeiro: Instituto Histórico e Geográfico Brasileiro, 1986.

Zahedieh, Nuala. "Trade, Plunder, and Economic Developments in Early English Jamaica, 1655-1689." The Economic History Review 39, no. 2 (1986): 205-22.

Zohar, Gil Stern. "Jewish Pirates of the Caribbean," The Jerusalem Post Magazine, 9 April 2016, http://www.jpost.com/Magazine/Jewish-pirates-of-the-Caribbean-447397. 